\title{
Growth of Sugar Cane Under Cultivation Flooded at Different Speeds Lowering of the Water Table
}

\author{
Antonio Clarette Santiago Tavares ${ }^{1}$, Sergio Nascimento Duarte ${ }^{2}$, Nildo da Silva Dias ${ }^{3}$, \\ Francisco Vanies da Silva Sá $a^{3}$ Jarbas Honorio de Miranda ${ }^{2}$, Kelly Tagianne Santos de Souza ${ }^{4}$, \\ Maria Alejandra Moreno Pizani ${ }^{2}$, Osvaldo Nogueira de Sousa Neto ${ }^{5} \&$ Cleyton dos Santos Fernandes ${ }^{3}$ \\ ${ }^{1}$ Federal Institute of Northern Minas Gerais, Almenara, MG, Brazil \\ ${ }^{2}$ Department of Biosystems Engineering, Luiz de Queiroz College of Agriculture, University of Sao Paulo, \\ Piracicaba, SP, Brazil \\ ${ }^{3}$ Center of Agrarian Sciences, Univerdidade Federal Rural do Semi-Árido, Mossoró, RN, Brazil \\ ${ }^{4}$ Department of Agrarian Sciences, Federal University of Roraima, Boa Vista, RR, Brazil \\ ${ }^{5}$ Department of Exact, Technological and Human Sciences, Federal Rural University of the Semi-Arid, Angicos, \\ RN, Brazil \\ Correspondence: Francisco Vanies da Silva Sá, Center of Agrarian Sciences, Federal Rural University of \\ Semi-Arid, Mossoró, RN, Brazil. Tel: 55-083-998-619-267. E-mail: vanies_agronomia@hotmail.com
}

Received: June 17, 2018

doi:10.5539/jas.v10n10p122
Accepted: July 31, $2018 \quad$ Online Published: September 15, 2018

URL: https://doi.org/10.5539/jas.v10n10p122

\begin{abstract}
In order to study the effect of downgrade rate of water table in the growth of sugar cane (Saccharum spp, cultivate 867515), an experiment in was carried under randomized block design with factorial arrangement ( $3 \times$ $5+1)$ and 4 replications, applying the flood irrigation system in 3 stages of development $(67,210$ and 300 days after planting - DAP) with 5 downgrade rate of water table (3, 6, 9, 12 and 15 days) and the control (no flood). The plants were grown in soil columns of 240 liters, filled with Yellow Oxisol by 300 days after planting and monitored as the height of the stem, number of leaves, stem diameter, number of internodes, number of tillers, leaf area, growth increment, rate relative growth, leaf area index, leaf area ratio and specific leaf area. The stages of development that the flooding was applied at a rate of lowering of the groundwater level variables influenced the growth of cane sugar. The plants drenched at 210 days after planting for 12 days had higher growth of stem, leaf number, leaf area and leaf area index. Plants exposed to water logging after 67 and 210 days after planting obtain better physiological indices that the witness and those who received the 305 DAP waterlogging. It is recommended that the spacing between drains is estimated to be able to lower the water table, after a reloading project to $30 \mathrm{~cm}$ deep in 15 days.
\end{abstract}

Keywords: drainage, physiological indices, waterlogging

\section{Introduction}

Sugarcane (Saccharum spp.) is a species of great economic importance in the world. In Brazil, the area cultivated with the species has increased every year, because of its use in the production of ethanol and refined sugar, with high economic value (Vale et al., 2011; Galon et al., 2012; Holanda et al., 2014; Ferraz et al., 2015).

To maximize the production of the crop, it is necessary to install irrigation or drainage systems. In the main regions of sugarcane cultivation in Brazil, drainage systems have become increasingly more frequent to remedy the deficiency in the natural drainage of the soil, allowing the profitable cultivation of sugarcane with sustainability, being mainly implemented in the states of São Paulo, Minas Gerais, Mato Grosso do Sul and Goiás, and in the 'Zona da Mata' of the Northeastern region.

Most drainage systems are projected based on the practical experience of the designer, without rational technical criteria. The necessity of artificial drainage and its dimensioning depend on the physical-hydraulic and geometric properties of the soil profile. Thus, the adoption of an empirical procedure is the main cause of failure in sugarcane cultivation in these areas with deficiency of drainage (Mingoti et al., 2006). 
Gava et al. (2011) report that the growth and development of sugarcane plants are affected by both the lack and excess of water supply. Soil variability makes it difficult the adoption of representative values for the physical-hydraulic and geometric properties of the soil profile. However, this problem can be overcome with a more detailed investigation at field (Messchmidt et al., 2015; Tavares et al., 2015).

Most studies have so far evaluated the effects of deficiency or temporary absence of oxygen in the soil, without the simultaneous verification of factors that may interfere with the capacity of the plants to tolerate anoxic stress. Thus, this study aimed to evaluate sugarcane growth in flooded cultivation at different speeds of water table lowering, in three development stages of the plant-cane cycle.

\section{Material and Methods}

The experiment was carried out in a greenhouse of the Department of Biosystems Engineering of the "Luiz de Queiroz" College of Agriculture-USP, in the municipality of Piracicaba-SP, Brazil (22 $42^{\prime}$ of latitude S; $47^{\circ} 38^{\prime}$ of longitude W and altitude of $540 \mathrm{~m}$ ) in October of 2007 to October of 2008. According to Köppen's classification, the climate of the region is Cwa, i.e., humid tropical, with 3 drier months (June, July and August), rainfalls in the summer and droughts in the winter, with mean temperature of the hottest month higher than $22^{\circ} \mathrm{C}$ and coldest month lower than $18^{\circ} \mathrm{C}$.

The study consisted in determining the production and maturation of sugarcane (Saccharum spp., cultivar RB 867515) under flooded cultivation and subsequently lowering the water table by $0.3 \mathrm{~m}$ at the speeds of $3,6,9,12$ and 15 days $\left(\mathrm{V}_{1}, \mathrm{~V}_{2}, \mathrm{~V}_{3}, \mathrm{~V}_{4}\right.$ and $\mathrm{V}_{5}$, respectively). In addition, there was a treatment with conventional irrigation, without flooding, to obtain values of plants not subjected to the stress $\left(\mathrm{T}_{1}=\right.$ control $)$.

The statistical design was randomized blocks, arranged in a $[(3 \times 5)+1] \times 4$ factorial scheme, i.e., 3 development stages in which the flooding was applied, 5 speeds of water table lowering and a control (without irrigation but without stress by the excess of moisture), forming 16 treatments with 4 replicates, totaling 64 plots.

The flooding depth was initially maintained above the soil surface at approximately $2 \mathrm{~cm}$ for 12 hours and, after this interval, the progressive lowering continued until the total drainage of the lysimeter. The moment of flooding was determined by the development stages of the crop, which were: a) initial development stage $\left(\mathrm{P}_{1}\right)$-at 67 days after planting (DAP); b) stage of slow development of the radicle system $\left(\mathrm{P}_{2}\right)$-at 210 DAP- $\mathrm{P}_{2}$ and c) stage in which the sugarcane has an accelerated development of its root system $\left(\mathrm{P}_{3}\right)$, i.e., close to harvest, when the stress can influence the qualitative value of the production - at 300 DAP- $\mathrm{P}_{3}$. Thus, the following combinations were obtained: $\mathrm{T}_{1}, \mathrm{P}_{1} \mathrm{~V}_{1}, \mathrm{P}_{1} \mathrm{~V}_{2}, \mathrm{P}_{1} \mathrm{~V}_{3}, \mathrm{P}_{1} \mathrm{~V}_{4}, \mathrm{P}_{1} \mathrm{~V}_{5}, \mathrm{~T}_{2}, \mathrm{P}_{2} \mathrm{~V}_{1}, \mathrm{P}_{2} \mathrm{~V}_{2}, \mathrm{P}_{2} \mathrm{~V}_{3}, \mathrm{P}_{2} \mathrm{~V}_{4}, \mathrm{P}_{2} \mathrm{~V}_{5}, \mathrm{~T}_{3}, \mathrm{P}_{3} \mathrm{~V}_{1}, \mathrm{P}_{3} \mathrm{~V}_{2}$, $\mathrm{P}_{3} \mathrm{~V}_{3}, \mathrm{P}_{3} \mathrm{~V}_{4}$ and $\mathrm{P}_{3} \mathrm{~V}_{5}$.

The sugarcane was cultivated in 64 lysimeters, which consisted of large waterproof concrete pipes, with height of $1.2 \mathrm{~m}$, diameter of $0.5 \mathrm{~m}$, planted area of $0.20 \mathrm{~m}^{2}$ and useful volume of $240 \mathrm{~L}$, installed in the experimental area. The containers were positioned in 4 rows of 16 pipes and each one of these containers represented one experimental plot.

Water was supplied to the lysimeters through two asbestos cement tanks, with capacity for $1000 \mathrm{~L}$ each, equipped with a float switch and placed on a wooden platform ( $2.5 \mathrm{~m}$ long, $1.6 \mathrm{~m}$ wide and $1.6 \mathrm{~m}$ high), located inside the greenhouse.

For water inlet and drainage, the lysimeters were perforated close to the bottom, where 19-mm-diameter PVC pipes were inserted, sealed with epoxy resin and gutter sealant. The pipes were $0.60 \mathrm{~m}$ long, with 5 -mm-diameter holes in its perimeter, spaced by $0.05 \mathrm{~m}$. A synthetic geotextile (Bidim OP-20) and a 0.10-m-thick layer of washed crushed stone were used to facilitate drainage and avoid the carrying of soil.

The pipes had an entry for water at the bottom part, connected to auxiliary mobile tanks that allowed to maintain the water table level inside the pipes at the desired depth.

The soil used to fill the lysimeters was collected in a profile of Red Yellow Latosol, with sandy loam texture, at the campus of the ESALQ/USP, called "Série Sertãozinho", removed from the layer of 0-0.50 m of its natural profile. Soil chemical and physical attributes (Table 1) were determined with the collection of disturbed samples. Soil liming was performed when the lysimeters were filled, by applying $2 \mathrm{Mg} \mathrm{ha}^{-1}$ of dolomitic limestone ( $40 \mathrm{~g}$ per lysimeter), homogenized with the soil in layers from $0.50 \mathrm{~m}$ on, from bottom to top, correcting a total soil layer of $0.30 \mathrm{~m}$. After filling the lysimeters, the water table level was raised to soil surface so that it accommodated and the limestone reacted. 
Table 1. Granulometric and chemical analyses of the soil used to fill the lysimeters

\begin{tabular}{|c|c|c|c|c|c|c|c|c|c|c|c|c|}
\hline Sand (\%) & & \multicolumn{3}{|c|}{ Silte (\%) } & \multicolumn{4}{|c|}{ Clay $(\%)$} & \multicolumn{4}{|c|}{ Real Density $\left(\mathrm{g} \mathrm{dm}^{-3}\right)$} \\
\hline 78 & & \multicolumn{2}{|c|}{4} & & & \multicolumn{2}{|c|}{18} & \multicolumn{5}{|c|}{2.86} \\
\hline $\mathrm{pH}$ & M.O & $\mathrm{P}$ & $\mathrm{S}$ & $\mathrm{K}^{+}$ & $\mathrm{Ca}^{2+}$ & $\mathrm{Mg}^{2+}$ & $\mathrm{Al}^{3+}$ & $\mathrm{H}^{+}+\mathrm{Al}^{3+}$ & SB & $\mathrm{T}$ & $\mathrm{V}$ & $\mathrm{M}$ \\
\hline $\mathrm{CaCl}_{2}$ & $--\mathrm{g} \mathrm{dm}^{-3}--$ & \multicolumn{2}{|c|}{$--\mathrm{mg} \mathrm{dm}^{-3}--$} & \multicolumn{7}{|c|}{ 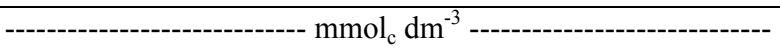 } & \multicolumn{2}{|c|}{----- \% ---- } \\
\hline 4.2 & 8 & 2 & 20 & 3.6 & 7 & 3 & 6 & 20 & 13.6 & 33.6 & 40 & 31 \\
\hline
\end{tabular}

Chemical fertilization was applied in 3 plots, guaranteeing full vegetative development and yield, using the following doses per hectare: $67 \mathrm{~kg}$ of nitrogen, $180 \mathrm{~kg}$ of $\mathrm{P}_{2} \mathrm{O}_{5}$ and $225 \mathrm{~kg}$ of $\mathrm{K}_{2} \mathrm{O}$, which corresponded to 10.5 , 20 and $10 \mathrm{~g}$ per lysimeter, respectively. Phosphate fertilization was applied at planting, using single superphosphate $\left(18 \%\right.$ of $\left.\mathrm{P}_{2} \mathrm{O}_{5}\right)$. Nitrogen and potassium were applied as top-dressing at 40, 110 and 220 DAP, using potassium nitrate $\left(45 \%\right.$ of $\mathrm{K}_{2} \mathrm{O}$ and $13 \%$ of $\left.\mathrm{N}\right)$. At 150 DAP, $5 \mathrm{~kg}$ of organic matter was incorporated in each plot, to improve aeration in the superficial soil layer, improving its structure and also promoting the reduction of the superficial soil temperature.

In the initial stage of plant cane, precautions were taken to promote ideal conditions of moisture for the sprouting and rooting of the setts. In the first $20 \mathrm{DAP}$, daily irrigations were performed using water from the supply system of the Department of Biosystems Engineering of the ESALQ-USP, to maintain the soil with satisfactory moisture. In the period from 20 to $30 \mathrm{DAP}$, the water table level was maintained at $0.30 \mathrm{~m}$ from the surface, through the utilized flooding system, because the root system was still in development, thus preventing the crop from suffering water stress. After 30 DAP, the water table level was lowered to $0.40 \mathrm{~m}$ from the surface to stimulate the development of the root system and, at this moment, tensiometers were installed in the plots at depth of 30 $\mathrm{cm}$.

The sugarcane crop was irrigated along its cycle, except in the period in which the flooding treatments were applied, guaranteeing that the obtained differences were caused only by the stress due to excessive moisture (hypoxia). After applying the treatments, the water table level was lowered to $0.80 \mathrm{~m}$ from the soil surface and the irrigation of these plants resumed when the reading of the tensiometers installed at depth of $0.30 \mathrm{~m}$ in the lysimeters reached the value of $50 \mathrm{kPa}$.

The utilized irrigation system was subirrigation, using the same flooding system of the lysimeters. The level of the auxiliary tank remained at $0.40 \mathrm{~m}$ deep and, when the readings of the tensiometers were above the specified tension, the valves of the tanks were opened and the water table level remained for a period of 24 hours. Thus, the water depth applied in each irrigation was sufficient to increase soil moisture again to close to field capacity $(6 \mathrm{kPa})$, characterized by the soil water retention curve. Irrigation was continuous and maintained until its stop, 45 days before cutting.

The biometric and physiological parameters relative to growth and development of sugarcane plants were monthly evaluated and are described below:

- Stem height: measured from the level of the soil until the top visible dewlap of the +1 leaf, according to the Kuijper system.

- Number of leaves: counted as the number of fully opened leaves (expanded) with at least $20 \%$ of green leaf area, from the +1 leaf, according to the leaf identification of the Kuijper system.

- Stem diameter: measured at the base of the stem, in the middle portion of the $3^{\text {rd }}$ internode, using a digital caliper.

- Number of internodes: evaluations consisted only in the count of the number of exposed internodes and the first evaluation occurred 90 days after planting.

- Number of tillers in the plot: all tillers were counted in each plot, along the entire plant-cane cycle, considered as tillers until the moment when the stems had the +3 leaf, i.e., three fully opened leaves (expanded).

- Leaf area (LA): The choice of the leaf to be used in the measurement followed the numbering proposed by Kuijper. The leaf area of each plot was obtained by the sum of the leaf areas of all stems of each plot.

- Growth increment: calculated by measuring the distance from the old +3 leaf (from the previous sampling) until the current +3 leaf, divided by the number of days elapsed between both samplings, Equation 1 . 


$$
C G I=\frac{P c u r-\text { Pold }}{\text { Nde }}
$$

Where, CGI: crop growth increment (m); Pcur: position of the current +3 leaf (m); Pold: position of the old +3 leaf $(\mathrm{m})$ and Nde: number of days elapsed between the measurements.

- Relative growth rate (RGR) is the growth of a plant or any organ, calculated using as the parameters the leaf area useful for photosynthesis and the net photosynthetic rate, in two successive samplings $\left(\mathrm{m} \mathrm{m}^{-1} \mathrm{day}^{-1}\right)$, which can be obtained by:

$$
R G R=\frac{\ln (L A f)-\ln (L A i)}{\Delta T}
$$

Where, RGR: relative growth rate, $\mathrm{m} \mathrm{m}^{-1} \mathrm{day}^{-1}$; Ln: natural logarithm; LAf: final leaf area, $\mathrm{m}^{2}$; Lai: initial leaf area, $\mathrm{m}^{2} ; \Delta \mathrm{T}$ : time interval between two consecutive measurements, days.

- Leaf area index (LAI) is the relationship between leaf area and the soil area shaded by the leaves, obtained through the calculation of the mean leaf area $\left(\mathrm{m}^{2}\right)$ of one plant, multiplied by the number of plants per square meter, as presented in Equation 3.

$$
L A I=\frac{A F}{A S} \cdot N p p
$$

Where, LA: leaf area, $\mathrm{m}^{2}$; As: area of soil, $\mathrm{m}^{2}$; Npp: number of plants per plot.

- Leaf area ratio (LAR) is a morphophysiological component, the ratio between the area responsible for the interception of luminous energy (LA) and $\mathrm{CO}_{2}$ and the total dry matter resulting from photosynthesis, calculated in $\mathrm{cm}^{2} \mathrm{~g}^{-1}$ and expressed by Equation 4 .

$$
L A R=\frac{L A}{T D M}
$$

Where, LAR: leaf area ratio, $\mathrm{m}^{2} \mathrm{~kg}^{-1}$; LA: leaf area, $\mathrm{m}^{2}$; TDM: total dry matter, $\mathrm{kg}$.

The specific leaf area (SLA) is an index that allows to evaluate if the plants are accumulating photoassimilates in their leaves or translocating to other sink organs, measured in $\mathrm{cm}^{2}$ day ${ }^{-1}$ and expressed by Equation 5 .

$$
S L A=\frac{L A}{L D M}
$$

Where, SLA: specific leaf area, $\mathrm{m}^{2} \mathrm{~kg}^{-1}$; LA: leaf area, $\mathrm{m}^{2}$; LDM: leaf dry matter, $\mathrm{kg}$.

The results were interpreted through the analysis of variance. Since the utilized factors were quantitative and qualitative, F test was applied along with the Tukey and Dunnett tests, at 0.05 probability level, to compare the means between the treatments and the treatments with the control, respectively.

\section{Results and Discussion}

There was a linear response of sugarcane growth in height as a function of the days of cultivation, regardless of the condition of the water table level, with mean increments of $0.0087 \mathrm{~m} \mathrm{day}^{-1}$ (Figure 1A). Between the treatments, the lowest and highest stem heights were observed in $\mathrm{P}_{2} \mathrm{~V}_{1}$ and $\mathrm{P}_{1} \mathrm{~V}_{3}$, with mean values of 1.06 and $1.26 \mathrm{~m}$, respectively, and a mean difference of $0.20 \mathrm{~m}$ (Figure 1B). The chronology of the evaluations (evaluated periods) demonstrates that the vegetative development of the plants was normal, as any plant that expresses its production in the form of biomass. Hence, it can be inferred that the speeds of lowering of the water table level in the plots that contained plants did not influence their development along the crop cycle.

The RGR of plants subjected to flooding at 210 DAP significantly differed from that of control plants and the excess of moisture in their root system was beneficial, promoting higher relative growth rate of leaf area (RGR) in these plants (Figure 1C). Among plants subjected to flooding, and later lowering of $0.30 \mathrm{~m}$ in 3, 6, 9, 12 and 15 days in the periods of 67,215 and 305 DAP, the RGR values were similar, $0.0049,0.0053$ and $0.0044 \mathrm{~m} \mathrm{~m}^{-1}$ day $^{-1}$, respectively; the difference occurred between plants stressed at 210 DAP $\left(0.0053 \mathrm{~m} \mathrm{~m}^{-1} \mathrm{day}^{-1}\right)$ and the control $\left(0.0036 \mathrm{~m} \mathrm{~m}^{-1} \mathrm{day}^{-1}\right)$, subjected only to irrigation. At $305 \mathrm{DAP}$, there was a slight reduction, although not significant, which would probably be different in the period of harvest. Silva et al. (2005) claim that this continuous decrease of RGR can be explained by the increment in respiratory activity and by the self-shading, whose importance increases with the age of the plant.

Stem diameter increased in the period from 90 to 150 days of cultivation, with later reductions until 300 days of cultivation (Figure 1D). The variation in stem diameter is due to the appearance of new stems between the evaluations, which leave the tillering stage and start to be evaluated as stems in development. The conditions under which the experiment was conducted favor the obtained mean values, because water availability is 
relevant for the maximization of yield gains. This is consistent with Oliveira et al. (2004), who found mean values of stem diameter equal to $0.0319 \mathrm{~m}$ in the cultivar RB72454 - progenitor of RB867515, for 18-month cultivation.

A

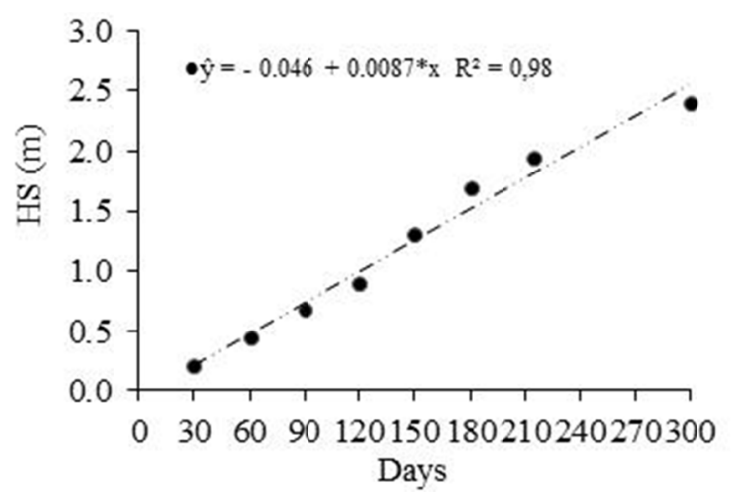

$\mathrm{C}$

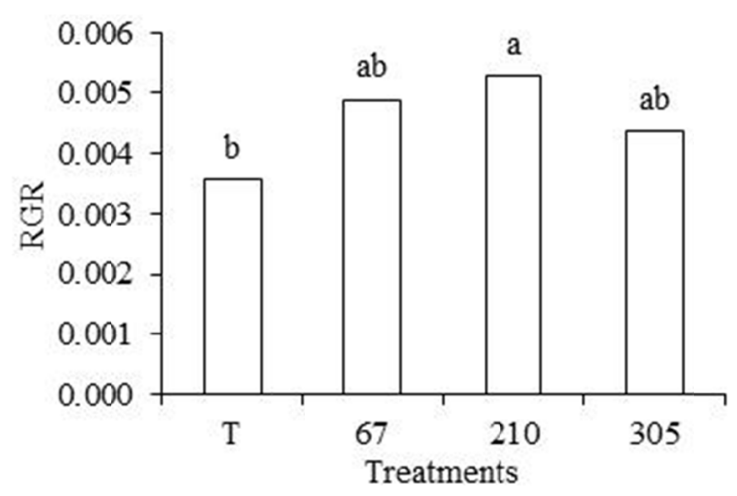

B

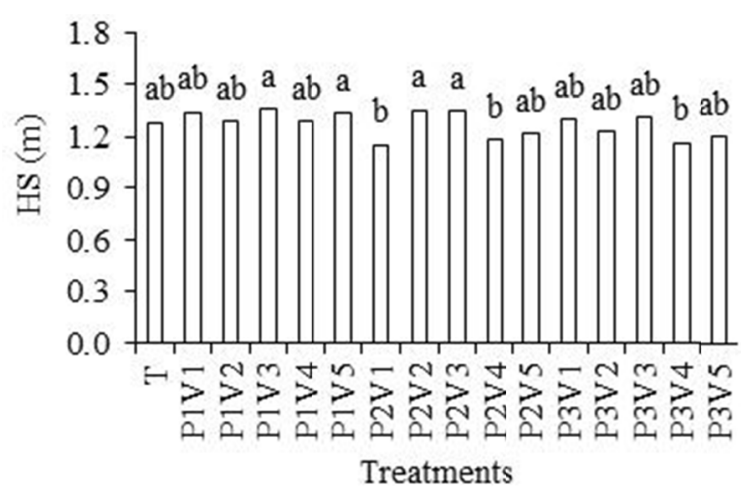

$\mathrm{D}$

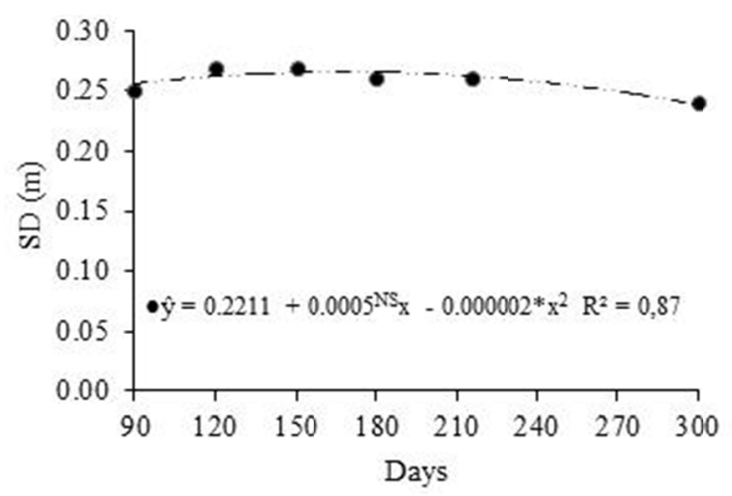

Figure 1. Means of height of sugarcane stems (HS) as a function of days after planting (A), height of sugarcane stems subjected to different treatments (B), relative growth rate (RGR) obtained in the plots considering the periods of water table lowering (C) and stem diameter (SD) of sugarcane as a function of days after planting (D)

Note. ${ }^{\text {NS }}$ and $*=$ Not significant and significant at $5 \%(\mathrm{p}<0.05)$ probability. Means followed by the same letter do not differ statistically by the Dunnett test at $5 \%$ probability.

Regarding the CGI, plants reached their maximum development at 120 DAP and remained until 150 DAP (February to March). After this phase, the internode elongation developed increasingly less (Figure 2A). Oliveira et al. (2005) studied the growth of sugarcane cultivars in Paraná and attributed the effect on the reduction of elongation rate to the increase in self-shading during the maturation period. Oliveira et al. (2004) also found that the period of greatest stem elongation coincided with the periods of highest LAI values. These maximum rates can be associated with the adequate supply of nutrients and water.

The number of tillers until 120 DAP remained close to 3, indicating that there was a uniform initial sprouting, which allows to claim that these tillers were the ones that transformed into stems, responsible for the production in the experiment (Figure 2B). From 120 DAP on, there was a reduction in the number of tillers in the plots, possibly due to the stress imposed on the plants with the flooding, as well as the environmental conditions, because, according to Suguitani (2001), tillering varies according to variety, environmental conditions and adopted level of management. In this experiment, the low number of tillers may have been caused by the pot condition, the reduced space between lysimeters in comparison to field plantations, and by the stress through the excess of moisture imposed on the plots. 
A

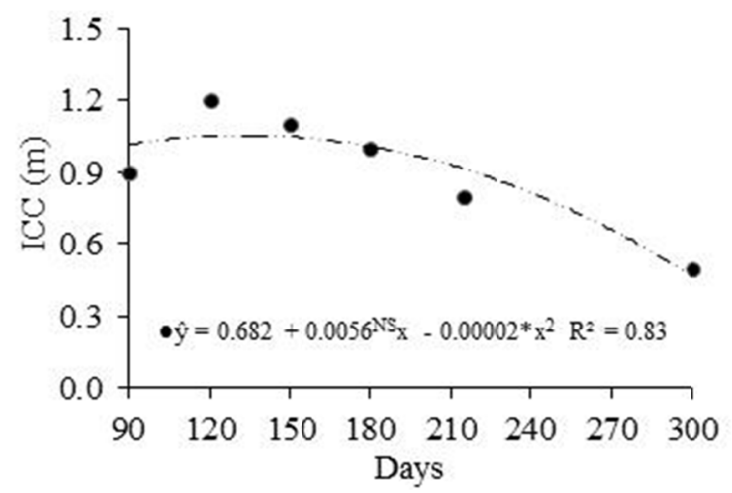

$\mathrm{C}$

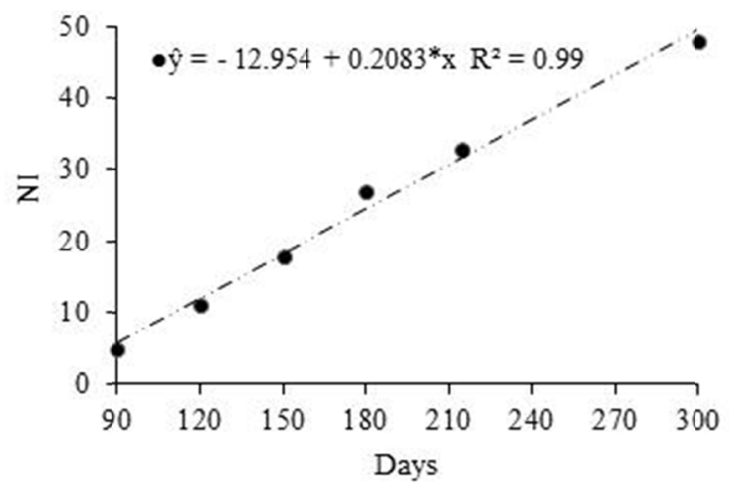

B

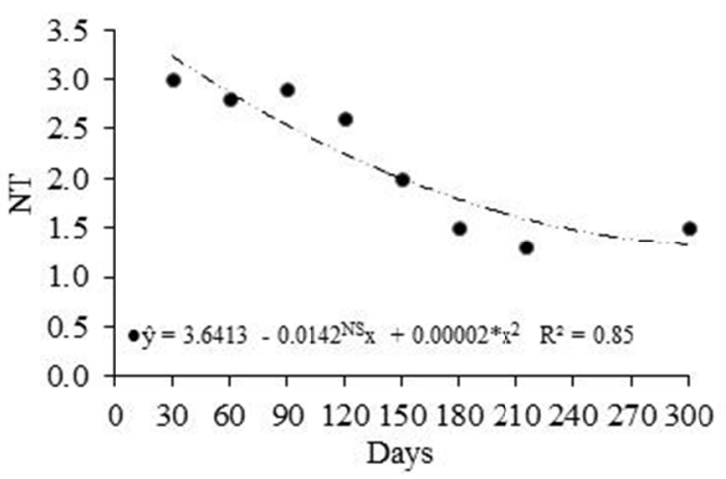

$\mathrm{D}$

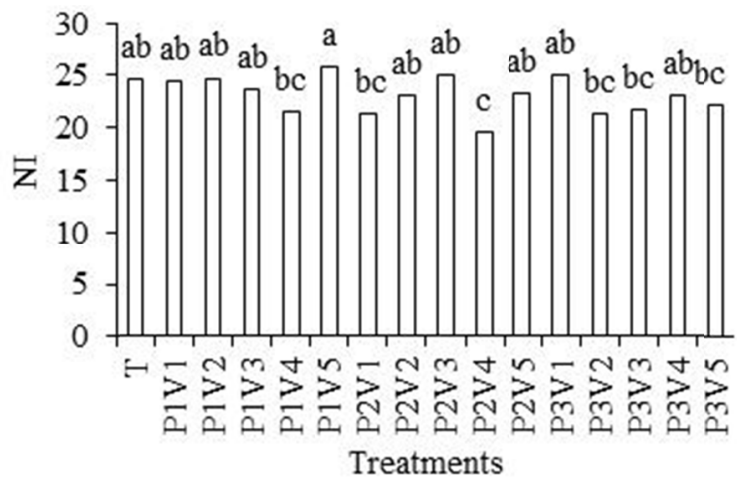

Figure 2. Means of growth increment of sugarcane stems as a function of days after planting (A), number of tillers of sugarcane stems (NT) as a function of days after planting (B), number of internodes (NI) in sugarcane stems as a function of days after planting $(\mathrm{C})$ and subjected to the different treatments (D)

Note. ${ }^{\text {NS }}$ and $*=$ Not significant and significant at $5 \%(\mathrm{p}<0.05)$ probability. Means followed by the same letter do not differ statistically by the Dunnett test at $5 \%$ probability.

The number of internodes expresses the increase in green matter of the plants along the cycle and the Figure 2C faithfully represents this development, since the number of internodes increases with the increment of days after planting. The mean number of internodes in the plots for the different treatments are shown in Figure 2D. The treatment $\mathrm{P}_{1} \mathrm{~V}_{5}$ showed the highest number of internodes (33), while $\mathrm{P}_{2} \mathrm{~V}_{4}$ exhibited the lowest number (25). Pedrosa et al. (2005) found maximum number of 23.4 internodes per plant and minimum number of 19.1, for the cultivar SP-79 1011.

As to the number of leaves, along the evaluations there was an increase until 215 DAP, period in which the plant expresses its maximum vegetative potential and, from this point on, enters the maturation stage, naturally reducing the number of leaves (Figure 3A). The 'year cane' (12-month cycle), planted in September-October, has its maximum development from November to April, decreasing after this period due to the adverse climatic conditions of the winter in the Center-South region; the phase of greatest development occurs in the first half of the long period. Ramesh (2000) reports that, after the stage of intense growth, the crop reduces the expenditure of energy for the production of green leaves.

Regarding the mean number of leaves in the treatments per plot, the treatment $\mathrm{P}_{1} \mathrm{~V}_{5}$ showed the highest mean number of leaves (19.4 leaves), not differing from the others, except from $\mathrm{P}_{2} \mathrm{~V}_{4}$ (Figure 3B). Oliveira et al. (2007), in an experiment with 1.5-year-cycle sugarcane (cultivar RB72454-progenitor of the studied cultivar), obtained at 213 DAP a mean number of 10 leaves; however, at 377 DAP, these authors recorded a mean number of approximately 6 leaves per tiller. Considering the different planting plans and the use of different cultivars, although with similar characteristics, as well as the pot condition, the plants evaluated in this study showed number of leaves consistent with a field cultivation found by the cited authors. 
A

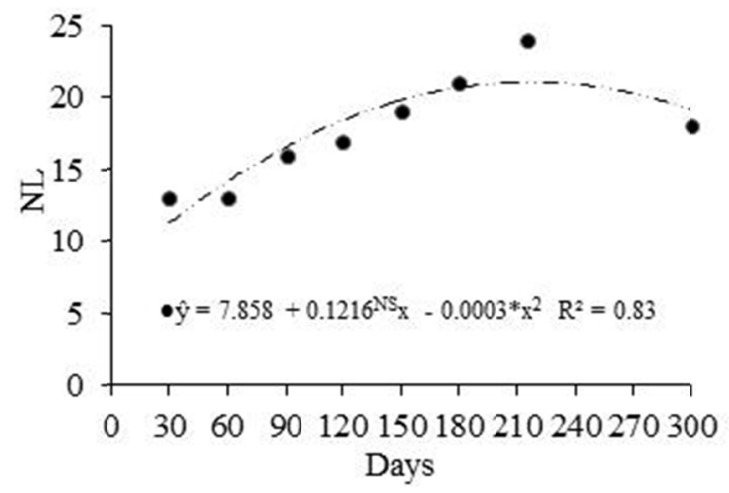

$\mathrm{C}$

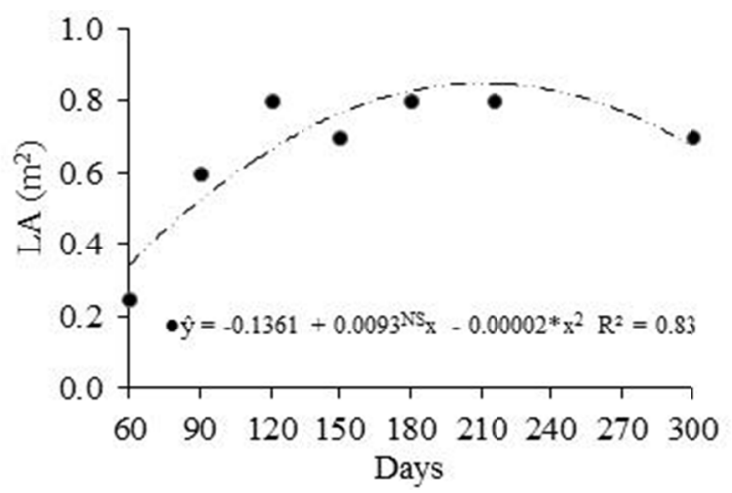

B

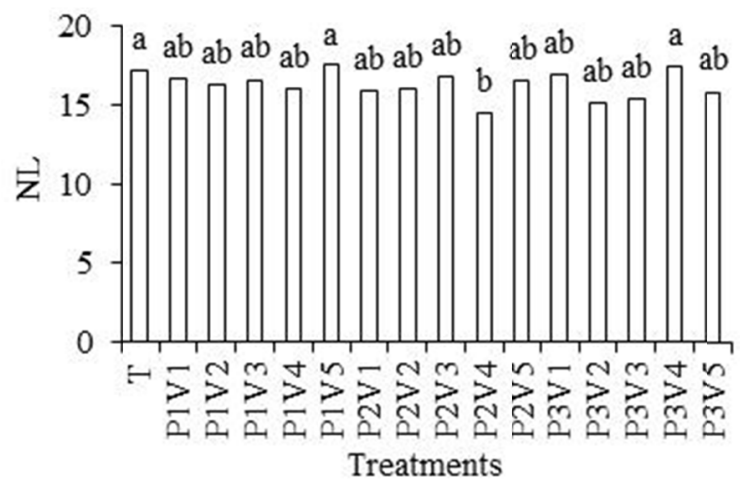

$\mathrm{D}$

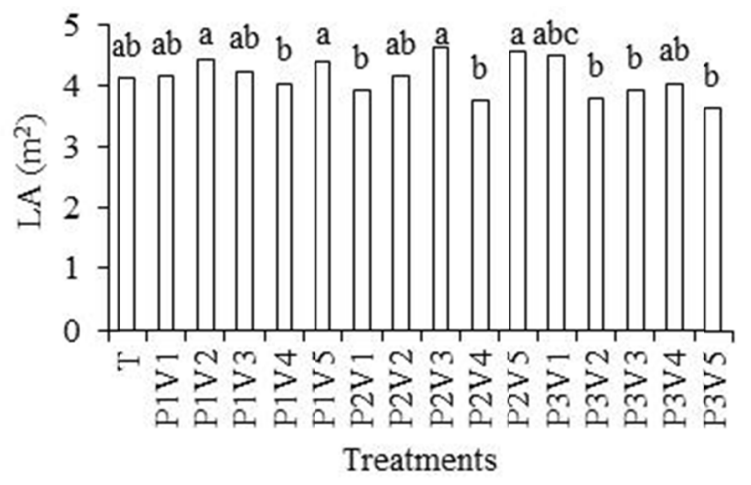

Figure 3. Means of number of leaves (NL) in sugarcane stems as a function of days after planting (A), subjected to the different treatments (B), leaf area (LA) of sugarcane as a function of days after planting (A) and Leaf area of sugarcane subjected to the different treatments (B)

Note. ${ }^{\text {NS }}$ and $*=$ Not significant and significant at $5 \%(\mathrm{p}<0.05)$ probability. Means followed by the same letter do not differ statistically by the Dunnett test at $5 \%$ probability.

Regarding the leaf area of the plants, the periods of 120 and 215 DAP stood out for showing leaf area values of 0.90 and $0.87 \mathrm{~m}^{2}$, respectively (Figure 3C). After 90 DAP, the leaf area remained between 0.6 and $0.9 \mathrm{~m}^{2}$, which is due to the capacity of renewal of the plants, because each stem produces a new leaf every 10 days, approximately. At the end of the cycle, until 300 DAP, the leaf area reduced again, because irrigation was suspended and the plants were in the maturation stage. This dry period at the end of the cycle is important to favor sucrose accumulation in the stems and to decrease the risk of flowering.

The treatments maintained a leaf area varying between 0.56 and $0.74 \mathrm{~m}^{2}$, for the treatments $\mathrm{P}_{2} \mathrm{~V}_{4}$ and $\mathrm{P}_{2} \mathrm{~V}_{5}$, respectively (Figure 3D). On the other hand, Oliveira et al. (2007), for the cultivar RB72454, obtained maximum mean leaf area of approximately $0.80 \mathrm{~m}^{2}$. For plants that did not suffer stress due to flooding, represented by the control (T), the mean value of leaf area was $0.70 \mathrm{~m}^{2}$, not differing from most treatments evaluated.

As to the leaf area index, the highest values occurred at 120 and 215 DAP (Figure 4A). The number of stems influences the LAI along the cycle, i.e., it leads to a greater active leaf area with higher biological yield of the crop. Since photosynthesis is the process responsible for the supply of energy necessary for plant growth and development; thus, it can be claimed that the higher the LAI and the longer the leaf area remains active, the higher the biological yield of the crop. From 120 DAP on, there is a reduction in the number of tillers in the plots, possibly due to the stress imposed on the plants with the flooding. However, after 215 DAP, the tillering resumed in the plots, possibly because of the conditions promoted by the organic material added to the plots at 150 DAP.

Since the LAI values are related to the mean leaf area, the treatments that showed the extreme values were control (T), with mean values of 3.54, and $\mathrm{P}_{2} \mathrm{~V}_{4}$, with mean values of 2.85 (Figure 4B). Except for the treatment $\mathrm{P}_{2} \mathrm{~V}_{4}$, the others did not differ significantly. Pistelli et al. (2012), working with flooding of Prunus cultivar Mr.S.2/5 rootstocks and its clones (S.1 and S.4), observed that after six days of exposure to flooding, plants of 
the clone S.1 were severely damaged, exhibiting wilting and strong epinasty of the leaves. However, this behavior was not observed in the present study, so that the reduction of leaf area is related to the fact that the photosynthetically active leaf area has already stabilized. After these periods, plants reduced the number of leaves and leaf area per plot, and this index was conditioned to the end of the plant-cane cycle.

A
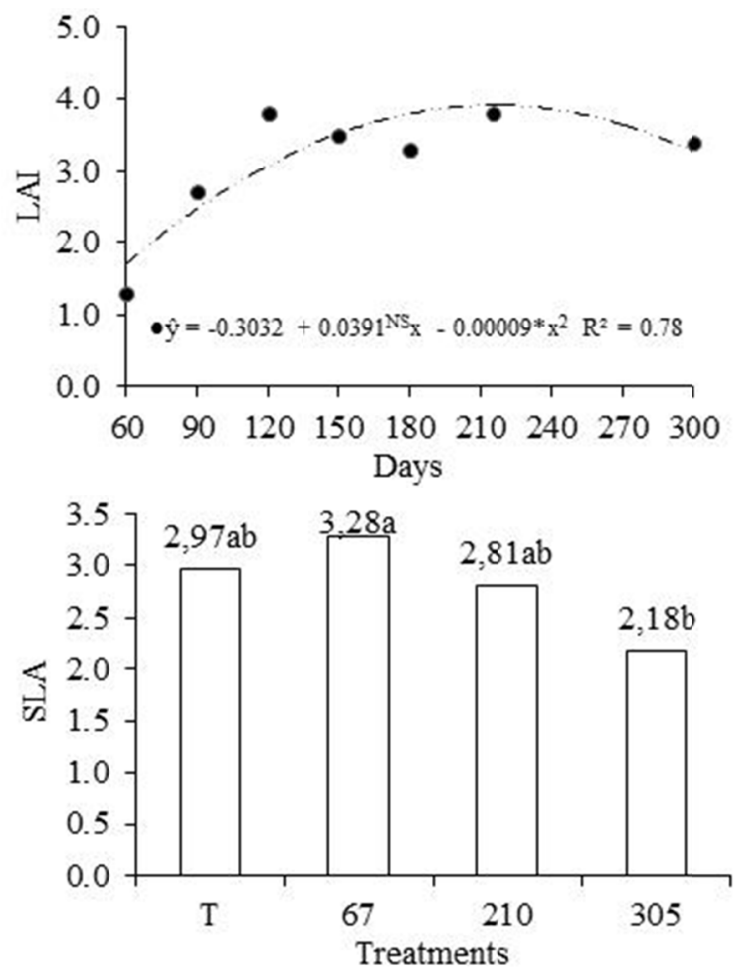

B
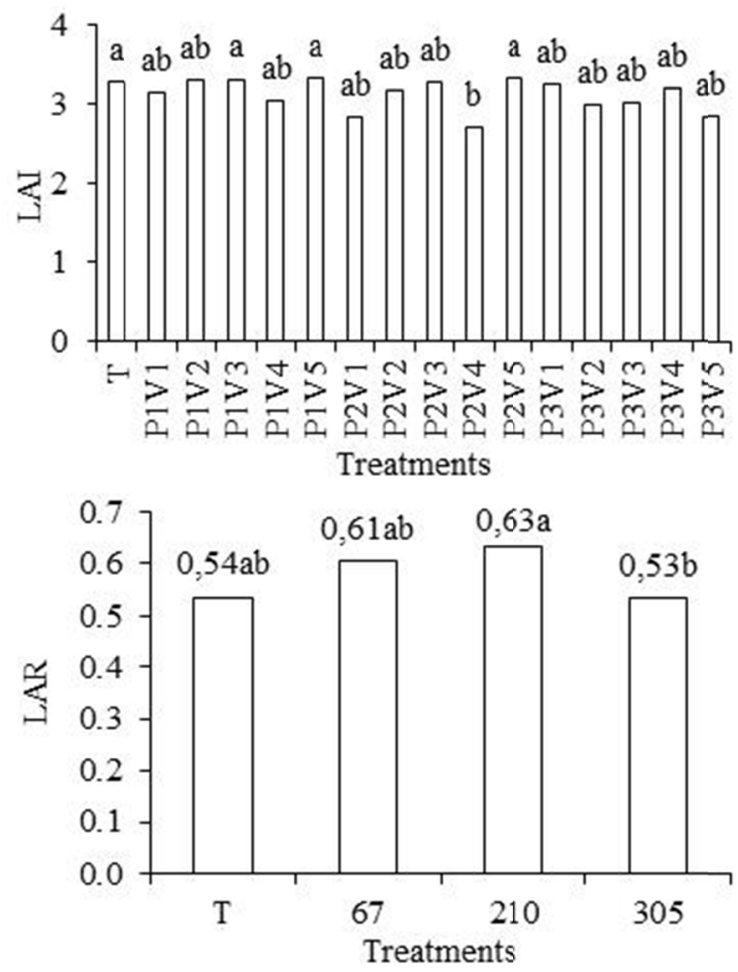

Figure 4. Means of leaf area index (LAI) of sugarcane as a function of days after planting (A), subjected to the different treatments (B), specific leaf area (SLA) obtained in the plots considering the periods of water table lowering (A) and leaf area ratio (LAR) obtained in the plots considering the periods of water table lowering (B)

Note. ${ }^{\mathrm{NS}}$ and $*=$ Not significant and significant at $5 \%(\mathrm{p}<0.05)$ probability. Means followed by the same letter do not differ statistically by the Dunnett test at $5 \%$ probability.

The SLA relates leaf surface with leaf dry matter, expressing the photosynthetic potential of the plants in the flooded plots. The SLA for the different levels of stress (lowering of $0.30 \mathrm{~m}$ in 3, 6, 9, 12 and 15 days in the periods of 67, 215 and $305 \mathrm{DAP}$ ) showed significant difference between the periods 67 and $305 \mathrm{DAP}$, with values of 3.28 and $2.18 \mathrm{~m}^{2} \mathrm{~kg}^{-1}$, respectively (Figure 4C). According to Grotkopp and Rejmánek (2007), large SLA allows higher efficiency to capture solar energy and it is through photosynthesis, under optimal nutritional conditions, that the competitive capacity becomes evident. Silva et al. (2005) found decreasing values along the development of the crop, demonstrating that the sugarcane crop translocates its reserves from leaves to other plant parts, especially stems.

The mean values of leaf area ratio (LAR) for the evaluated plants are presented in Figure 4D. The flooding caused at 210 DAP promoted LAR value of $0.63 \mathrm{~m}^{2} \mathrm{~kg}^{-1}$, differing statistically only from the mean value of 0.53 $\mathrm{m}^{2} \mathrm{~kg}^{-1}$ obtained when the flooding occurred at 305 DAP. There was a trend of reduction in the mean value of LAR as the plants approached the period of harvest. Silva et al. (2005), in their studies, reported decrease of this physiological index as the plant developed, and the potentiality of production of assimilation decreased.

\section{Conclusions}

The development stages in which the flooding was applied and the speeds of water table lowering influenced the sugarcane growth variables. 
Plants flooded at 210 DAP for 12 days obtained greater stem growth, number of leaves, leaf area and leaf area index.

Plants exposed to flooding at 67 and 210 DAP obtained better physiological indices in comparison to the control and those flooded at 305 DAP.

It is recommended that the spacing between drains be calculated to be able to lower the water table, after a recharge of project, to $30 \mathrm{~cm}$ deep in 15 days.

\section{References}

Ferraz, R. L. S., Barbosa, M. A., Batista, J. L., Magalhães, I. D., Dantas, G. F., \& Franco, F. O. (2015). Calagem em cana-de-açúcar: Efeitos no solo, planta e reflexos na produção. InterfacEHS-Saúde, Meio Ambiente e Sustentabilidade, 10(1), 166-177.

Galon, L., Tironi, S. P., Silva, A. F., Beutler, A. N., Rocha, P. R. R., Ferreira, E. A., \& Silva, A. A. (2012). Disponibilidade de macronutrientes em cultivares de cana-de-açúcar submetidas à competição com Brachiaria brizantha. Ciência Rural, 42(8), 1372-1379. https://doi.org/10.1590/S0103-84782012000800007

Gava, G. J., De C., Silva, M. De A., Silva, R. C. Da, Jeronimo, E. M., Cruz, J. C. S., \& Kölln, O. T. (2011). Produtividade de três cultivares de cana-de-açúcar sob manejos de sequeiro e irrigado por gotejamento. Rev. Bras. de Eng. Agrí. e Amb, 15(3), 250-255. https://doi.org/10.1590/S1415-43662011000300005

Grotkopp, E. and Rejmánek, M. (2007) High Seedling Relative Growth Rate and Specific Leaf Area Are Traits of Invasive Species: Phylogenetically Independent Contrasts of Woody Angiosperms. American Journal of Botany, 94(4), 526-532. https://doi.org/10.3732/ajb.94.4.526

Holanda, L. A., Santos, C. M., Sampaio Neto, G. D., Sousa, A. P., \& Silva, M. A. (2014). Variáveis morfológicas da cana-de-açúcar em função do regime hídrico durante o desenvolvimento inicial. Irriga, 19(4), 573-584. https://doi.org/10.15809/irriga.2014v19n4p573

Messchmidt, A. A., Bianchi, V. J., Zanandrea, I., Martinazzo, E. G., Radmann, E. B., \& Bacarin, M. A. (2015). Trocas gasosas e atividade antioxidante de portaenxertos de Prunus spp. submetidos ao estresse seca e alagamento. Rev. de la Facultad de Agron, 114(1), 71-81.

Mingoti, R., Duarte, S. N., Miranda, J. H., \& Cruciani, D. E. (2006). Dimensionamento econômico de profundidades e espaçamentos de drenos para a produção de cana-de-açúcar. Rev. Bras. de Eng. Agrí. e Ambi, 10(3), 535-540. https://doi.org/10.1590/S1415-43662006000300001

Oliveira, R. A., Daros, E., Zambon, J. L. C., Weber, H., Ido, O. T., Zuffellato-Ribas, K. C., Koehler, H. S., \& Silva, D. K. T. (2004). Crescimento e desenvolvimento de três cultivares de cana-de-açúcar, em cana-planta, no estado do Paraná. Scientia Agraria, 5(1), 87-94. https://doi.org/10.5380/rsa.v5i1.1102

Oliveira, R. A., Daros, E., Zambon, J. L. C., Weber, H., Ido, O. T., Zuffellato-Ribas, K. C., Koehler, H. S., \& Silva, D. K. T. (2005). Crescimento e desenvolvimento de três cultivares de cana-de-açúcar, em cana-planta, no estado do Paraná: taxas de crescimento. Scientia Agrária, 6(1), 85-89. https://doi.org/10.5380/ rsa.v6i1.4599

Oliveira, R. A., Daros, E., Zambon, J. L. C., Weber, H., Ido, O. T., Bespalhok-Filho, J. C., Zuffellato-Ribas, K .C., \& Silva, D. K. T. (2007). Área foliar em cana-de-açúcar e sua correlação com produção de biomassa. Pesq. Agrop. Tropical, 37(2), 71-76.

Pedrosa, R. M. B., Dantas Neto, J., Santos, J. S., Albuquerque, W. G., Farias, C. H. A., \& Azevedo, H. M. (2005). Avaliação dos parâmetros dos colmos da cana-de-açúcar, segunda folha, submetida a níveis de irrigação e adubação. Rev. de Bio. e Ciên. da Terra, 5(1), 1-5.

Pistelli, L., Lacona, C., Miano, D.: Cirilli, M., Colao, M. C., Mensuali-Sodi, A., \& Muleo, R. (2012). Novel Prunus rootstock somaclonal variants with divergent ability to tolerate waterlogging. Tree Physiology, 32(3), 355-368. https://doi.org/10.1093/treephys/tpr135

Ramesh, P. (2000). Effect of different levels of drought during the formative phase on growth parameters and its relationship with dry matter accumulation in sugarcane. J. of Agron. Crop Science, 185(1), 83-89. https://doi.org/10.1046/j.1439-037x.2000.00404.x

Silva, D. K. T., Daros, E., Zambon, J. C., Weber, H., Ido, O. T., Zuffellato-Ribas, K. C., Koehler, H., \& Oliveira, R. A. (2005). Análise de crescimento em cultivares de cana-de-açúcar em cana-soca no noroeste do Paraná na safra de 2002/2003. Scientia Agraria, 6(1), 47-53. https://doi.org/10.5380/rsa.v8i1.8341 
Suguitani, C. (2001). Fenologia da cana-de-açúcar (Saccharum spp.) sob efeito do fósforo (p. 79). Dissertação (Mestrado na área de Fitotecnia) - Escola Superior de Agricultura "Luiz de Queiroz," Universidade de São Paulo, Piracicaba.

Tavares, A. C. S., Duarte, S. N., Miranda, J. H., Dias, N. S., Souza, K. T. S., \& Arraes, F. D. D. (2015), Velocidade de rebaixamento do nível freático na qualidade do caldo da cana-de-açúcar. Irriga, 20(3), 458-472. https://doi.org/10.15809/irriga.2015v20n3p458

Vale, D. W., Prado, R. M., Avalhães, C. C., \& Hojo, R. H. (2011). Omissão de macronutrientes na nutrição e no crescimento da cana-de-açúcar cultivada em solução nutritiva. Rev. Bras. de Ciên. Agrá, 6(2), 189-196. https://doi.org/10.5039/agraria.v6i2a550

\section{Copyrights}

Copyright for this article is retained by the author(s), with first publication rights granted to the journal.

This is an open-access article distributed under the terms and conditions of the Creative Commons Attribution license (http://creativecommons.org/licenses/by/4.0/). 